NBER WORKING PAPER SERIES

U.S. TRADE POLICY IN HISTORICAL PERSPECTIVE

Douglas A. Irwin

Working Paper 26256

http://www.nber.org/papers/w26256

NATIONAL BUREAU OF ECONOMIC RESEARCH
1050 Massachusetts Avenue
Cambridge, MA 02138
September 2019

I am grateful to Gene Grossman for helpful comments. This paper is forthcoming in the Annual Review of Economics. 10.1146/annurev-economics-070119-024409. The views expressed herein are those of the author and do not necessarily reflect the views of the National Bureau of Economic Research.

NBER working papers are circulated for discussion and comment purposes. They have not been peer-reviewed or been subject to the review by the NBER Board of Directors that accompanies official NBER publications.

(C) 2019 by Douglas A. Irwin. All rights reserved. Short sections of text, not to exceed two paragraphs, may be quoted without explicit permission provided that full credit, including () notice, is given to the source. 
U.S. Trade Policy in Historical Perspective

Douglas A. Irwin

NBER Working Paper No. 26256

September 2019

JEL No. F13,N71,N72

\begin{abstract}
$\underline{\text { ABSTRACT }}$
This survey reviews the broad changes in U.S. trade policy over the course of the nation's history. Import tariffs have been the main instrument of trade policy and have had three main purposes: to raise revenue for the government, to restrict imports and protect domestic producers from foreign competition, and to reach reciprocity agreements that reduce trade barriers. These three objectives - revenue, restriction, and reciprocity - accord with three consecutive periods in history when one of them was predominant. The political economy of these tariffs has been driven by the interaction between political and economic geography, namely, the location of trade-related economic interests in different regions and the political power of those regions in Congress. The paper also addresses the impact of trade policies on the U.S. economy, such as the welfare costs of tariffs, the role of protectionism in fostering American industrialization, and the relationship between the Smoot-Hawley tariff and the Great Depression of the 1930s.
\end{abstract}

Douglas A. Irwin

Department of Economics

Dartmouth College

Hanover, NH 03755

and NBER

douglas.irwin@dartmouth.edu 


\section{U.S. Trade Policy in Historical Perspective}

\section{Introduction}

A country’s trade policy affects the prices that prevail in its domestic market and therefore the allocation of the country's resources. It should come as no surprise, therefore, that trade policy is politically contentious because dollars and jobs are at stake whenever import duties are adjusted up or down. As a result, trade policy issues have been a perennial part of the American political debate.

This article focuses on what can be learned from the history of U.S. trade policy. It will address some of the key questions about the political economy of trade policy and the economic impact of those policies. This brief survey will not address how international trade itself has shaped the U.S. economy, but concentrate on the factors driving trade-policy outcomes and the economic consequences of some of those policy outcomes. In doing so, I draw extensively on my recent book Clashing over Commerce: A History of U.S. Trade Policy, which provides a comprehensive look at historical evolution of U.S. trade policy.

Section 2 provides an overview of the three main purposes of imports tariffs - revenue, restriction, and reciprocity, as will be explained below - and the three eras in which one of those purposes was predominant. The interplay between political and economic geography will be examined as some of the key political economy factors shaping trade policy. Along with the rules of the political system, these underlying factors ensure that policy is stable and has a strong status-quo bias. Section 3 examines how the history of U.S. trade policy sheds light on the classic issues of gains from trade and costs of protection. Section 4 looks at the impact of trade policy on the American economy by addressing three long-standing historical questions: How large were the economic stakes in the contentious North-South conflict prior to the Civil War? 
Did protective tariffs accelerate U.S. industrialization and promote economic growth in the late nineteenth century? Did the Smoot-Hawley tariff of 1930 spark a trade war that led to the Great Depression? Section 5 offers some concluding thoughts.

\section{Three Eras of U.S. Trade Policy}

International trade consists of exchanging exports of domestic goods and services for imports of foreign goods and services. Governments can either encourage this trade with subsidies or discourage it with taxes. This gives us four possible trade policies to consider: export taxes, export subsidies, import taxes, and import subsidies.

With respect to the United States, two of these four policies have little relevance: import subsidies are almost never employed by any country, the United States being no exception, and export taxes are expressly prohibited under article 1 , section 9 of the Constitution. ${ }^{1}$ This leaves export subsidies and import taxes. The United States has sometimes employed export subsidies, but never on a large scale because of their budgetary cost. ${ }^{2}$ Instead, import tariffs have been the central focus of U.S. trade policy since the establishment of the federal government in $1789 .^{3}$

What objective is a government trying to achieve in levying taxes on imports? Three objectives stand out: to raise revenue for the federal government, to restrict imports and protect domestic producers from foreign competition, and to achieve reciprocity through agreements that reduce trade barriers. In Clashing over Commerce, I dub these the "three R's” of trade policy: revenue, restriction, and reciprocity.

\footnotetext{
${ }^{1}$ At the constitutional convention of 1787, Southern states insisted that export taxes be banned. These states produced most of the nation's exports and feared that Northern states would enact such taxes at their expense; see Irwin $(2017,64)$.

2 The Export-Import Bank was created in 1934 to provide credit guarantees for exporters, but its overall financial support for exports has been small. For a history of the bank, see Becker and McClenahan 2003.

${ }^{3}$ Import quotas and voluntary export restraints were infrequently used policy instruments until the mid-twentieth century.
} 
At any point in time, all three objectives can be in play. Yet the history of U.S. trade policy can be divided into three eras in which one of them is predominate. From 1790 to 1860, revenue considerations were paramount in the setting of tariffs because import duties raised about 90 percent of receipts of the federal government. From 1861 to 1933, government revenue came increasingly from domestic taxes and therefore import duties were imposed mainly to protect domestic producers from foreign competition. ${ }^{4}$ And from 1934 until 2016, the primary goal of trade policy has been to reach trade agreements with other countries, either multilaterally through the General Agreement on Tariffs and Trade (GATT) and the World Trade Organization (WTO), regionally in agreements such as the North American Free Trade Agreement (NAFTA) or the Central American Free Trade Agreement (CAFTA), or bilaterally in agreements with countries such as Israel, Singapore, Australia, Korea, and others. (To judge from his Tweets, President Trump approves of tariffs for their ability to achieve all three goals of revenue, restriction, and reciprocity simultaneously.)

Figure 1 shows the average tariff on total and dutiable imports from 1790 to $2018 .{ }^{5}$ The average tariff on total imports includes imports of all goods (dutiable and duty-free), whereas the average tariff on dutiable imports includes goods that are subject to import duties. A large gap between these two series appeared after the Civil War when some products (such as coffee and tea, bananas and tin) were put on the duty-free list. These items were generally not produced in the United States so that no domestic producer would be harmed by giving the goods free entry.

\footnotetext{
${ }^{4}$ After the Civil War, the federal government introduced other domestic taxes to raise revenue and import duties accounted for only about half of the government's revenue. The revenue effects of tariffs were still important, as Irwin (1998b) shows in the context of the Laffer Curve, but the goal of protecting import-competing producers was considered more important. After the introduction of the income tax in 1913, import duties accounted for a very small fraction of government revenue.

${ }^{5}$ This series is based on tariff revenue divided by total imports or dutiable imports. As has long been recognized, this measure is far from perfect, but there is no ideal single measure of a country's tariff policy. See Anderson and Neary (2005) and Irwin (2010).
} 
Since the 1980s, free-trade agreements have also allowed some countries to export their goods to the United States without facing any duties. Setting aside such imports, the average tariff on dutiable imports can be interpreted, somewhat simplistically but still usefully, as the average degree of protection given to domestic producers facing foreign competition.

In Figure 1, one can see a rough delineation of these three eras. In the revenue period from 1790 to 1860, average tariffs rose from about 20 percent to 60 percent and then fell back down to 20 percent. In the restriction period from 1861 to 1933, the average tariff on dutiable imports jumped to 50 percent and remained at about that level for several decades. In the reciprocity period from 1934 to the present, the average tariff fell sharply, and then leveled off at about 5 percent. (In 2018, there is a very slight uptick in the average tariff as a result of the Trump administration's duties on imports from China and on imports of steel.) 
Figure 1: Average tariff on dutiable and total imports, 1790-2018

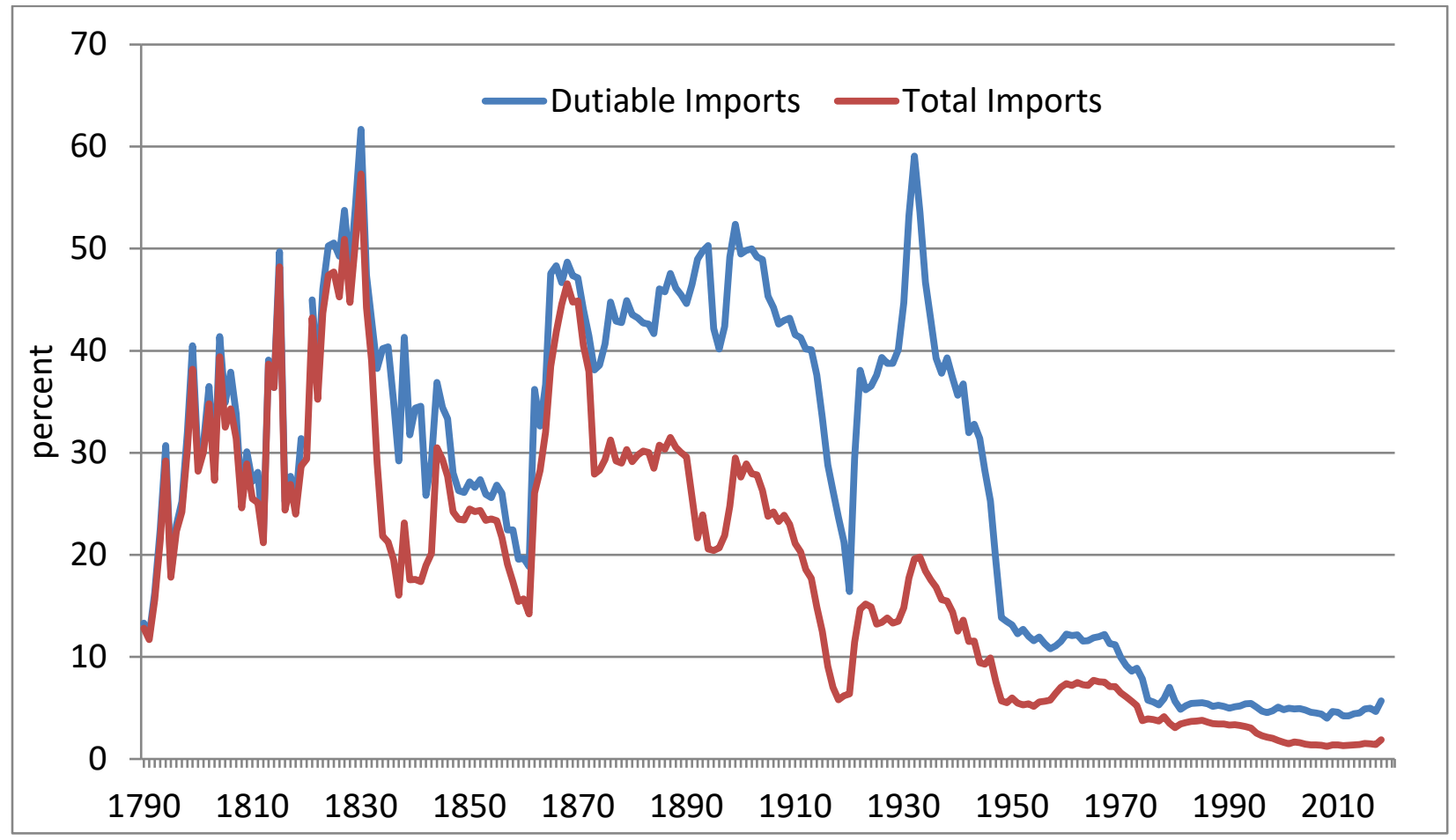

Source: Irwin (2017, 6), updated with data from the U.S. International Trade Commission.

Shifts in the average tariff often reflect deliberate changes in tariff rates enacted by Congress in legislation or negotiated by the president in trade agreements. ${ }^{6}$ Yet most tariff acts and trade agreements maintained the continuity of existing policy by making only incremental changes to the structure and rate of import duties. Many of the fluctuations seen in Figure 1 do not reflect deliberate policy actions by the government, but movements in import prices interacting with specific duties, which are a tax of a particular dollar amount per imported quantity rather than a percent of the import value. For most of U.S. history, specific duties comprised about two thirds of the rates in the tariff schedule. The ad valorem equivalent of

\footnotetext{
${ }^{6}$ From 1815 to 1930 (excluding the Civil War), Congress enacted 19 major revisions to the tariff schedule, about every 6 years.
} 
specific duties is inversely related to the price of imports. ${ }^{7}$ As a result, exogenous fluctuations in import prices have sometimes produced large changes in average tariffs, even when there was no change in the actual rates of duty set by policymakers and applied to imports.

For example, the sharp rise in prices during World War I followed by their equally sharp fall after the war moved tariffs down and up and largely account for the downward spike in Figure 1. Similarly, severe deflation during the Great Depression in the early 1930s followed by rising prices in the mid-1930s helps account for the upward spike in tariffs during that period. Most of the dramatic reduction in the average tariff during and after World War II reflects the higher inflation of that period. The average tariff on dutiable imports dropped from 33 percent in 1944 to 12 percent in 1950; about two thirds of this decline was driven by higher prices and one third by the tariff reductions negotiated at the first GATT conference in 1947. Irwin (1998a) finds that about 80 percent of the decline in tariffs from their peak in the early 1930s to the early 1950s was due to higher prices.

Although the average tariff on dutiable imports has fluctuated considerably over time, the underlying tariff rates chosen by policymakers have been much more stable than the figure suggests. The basic levels are set by policymakers to achieve the objectives of revenue, restriction, or reciprocity. What political economy factors help determine the average height of import duties and their structure across goods?

\subsection{Political Economy and Policy Stability}

Under the Constitution, Congress has the primary authority over trade policy and therefore it is the principal forum in which decisions about tariffs have been made. From 1790-

\footnotetext{
${ }^{7}$ See Crucini 1994 and Irwin 1998a. For example, a \$5 specific duty on a \$100 shirt would amount to a 5 percent ad valorem duty. If the shirt's price fell to $\$ 50$, the ad valorem equivalent would rise to 10 percent; if the shirt's price rose to $\$ 200$, the ad valorem equivalent would fall to 2.5 percent.
} 
1930, Congress voted on legislation that set the rates of duty on all imports. Beginning in 1934, however, Congress began delegating to the president the authority to negotiate trade agreements and no longer votes on the tariff schedule itself. Congress now occasionally votes on whether to grant such negotiating authority and, since 1979, on any agreements submitted by the president. ${ }^{8}$

The standard assumption is that members of Congress seek to be reelected and therefore vote on legislation in a way that satisfies the interests of their constituents. ${ }^{9}$ These constituent interests tend to be producers, not consumers, because producers are usually better organized for political action and employ many workers who are voters. The nation's Founding Fathers recognized that various factions would seek to pressure legislators to vote for their own economic benefit, especially on trade policy. As James Madison wrote in Federalist 10: "Shall domestic manufactures be encouraged, and in what degree, by restrictions on foreign manufactures? are questions which would be differently decided by the landed and the manufacturing classes, and probably by neither with a sole regard to justice and the public good.” He was pessimistic about whether "enlightened statesmen will be able to adjust these clashing interests, and render them all subservient to the public good.” That concern, in part, is why the founders created a political system that made the passage of legislation difficult, thereby forcing different factional interests to compromise with each other.

The nation's producer interests are not uniformly distributed across the country because different regions specialize in different economic activities. This regional specialization can

\footnotetext{
${ }^{8}$ In the grants of negotiating authority since 1934, the president has been authorized to reduce tariffs by up to a certain percentage. Starting with the Tokyo Round of trade negotiations (1973-79), international agreements have gone beyond tariffs to include the regulation of nontariff barriers. These provisions require changes in domestic law and hence Congressional approval is required.

9 This is a reasonable presumption because this is how members of Congress behave and even what they tell us. In 1881, Senator Thomas Bayard observed: "The member of the Senate and House are the advocates and representatives of different local interests all of which naturally seek to influence the transactions of the government on their own behalf.” Quoted in Irwin 2017, 700n81.
} 
persist for many decades. ${ }^{10}$ For example, for about two centuries, cotton has been produced in Mississippi and Alabama, corn in Iowa and Illinois, wheat in Kansas and Nebraska, tobacco in Kentucky and North Carolina, sugar in Louisiana and Florida, coal in Pennsylvania and West Virginia, iron and steel in Pennsylvania and Ohio, and farm equipment in Illinois and Indiana. In the twentieth century, automobiles have been produced in Michigan, aircraft in Washington, and high-technology and intellectual-property-intensive products in California, and so forth.

The persistence of this regional specialization is consistent with region-specific resource endowments (such as arable land suitable for certain crops) or locational advantages that imply significant adjustment costs in moving capital and labor between regions. These factors lock in a state's production pattern for many decades. Political economy models of trade policy, such as Baldwin (1984) or Grossman and Helpman (1994), reflect this fact by using a specific factors framework, wherein capital and labor employed in a particular industry are not mobile across sectors of the economy. This framework implies that trade-related interests cut along industry lines, depending on whether they produce goods for export or produce goods facing competition from imports: workers in exporting industries have an interest in low tariffs and workers in industries competing against imports have an interest in high tariffs. ${ }^{11}$

Just as the geography of production tends to be stable over time, the pattern of trade - the types of goods a country exports and imports - also tends to be stable over time. This is because the deep determinants of trade (technology and factor endowments) evolve slowly. Being

\footnotetext{
${ }^{10}$ As Holmes and Stevens (2004, p. 2008) note, "For industries producing nontradable goods or services like retail, there is little [geographic] specialization, while for tradable goods like manufactures, mining output, and agricultural products, there is a substantial amount of specialization across regions.”

${ }^{11}$ Other models focus on mobile factors of production and have political divisions based on different interests of those factors (landowners, capital owners, different types of labor, etc.) rather than industry; see Hiscox (2002) for historical evidence and Blonigen (2011) for recent evidence on the question of specific versus mobile factors. Median voter models that treat trade policy decision as a national referendum, such as Mayer (1984), are an interesting benchmark, but models that emphasize legislative voting, such as Grossman and Helpman (2005), are more in line with historical experience.
} 
resource rich, the United States has tended to export land-intensive agricultural products and resource-intensive manufactured goods. For most of the nineteenth century, the United States exported cotton, wheat, and other agricultural produce and imported manufactured goods and consumer products (coffee) or raw materials (tin). Due to its high land-to-labor ratio, the United States has always been a high wage country and a net importer of unskilled labor-intensive manufactured goods, such as textiles and apparel. ${ }^{12}$

The stable geographic location of domestic production and the stable composition of foreign trade means that regional economic interests are stable over time. Both factors produce a stable political geography of Congressional voting on trade policy. Of course, should an industry’s geographic location shift or the composition of trade change, regional economic interests will be affected and Congressional voting patterns would adjust accordingly. A good example of an industry changing its geographic location is the gradual migration of the cotton textile industry from New England, where it originally arose in the early nineteenth century, to the South in the early twentieth century. A key example of a changing trade pattern is America's shift from being a net importer to a net exporter of manufactured goods in the late nineteenth century due to the exploitation of mineral resources. ${ }^{13}$ Yet such changes tend to happen gradually, which again means that stability is the general rule.

These claims about the stability of policy are supported by looking at the geographic configuration of Congressional voting, the structure of the tariff over time, and the pattern of partisanship over trade issues.

\footnotetext{
${ }^{12}$ Of course, cotton exports were based on the mass use of unskilled (slave) labor before the Civil War.

${ }^{13}$ In the mid-1890s, the United States became a net exporter of natural-resource-intensive manufactured goods, which slowly began to crowd out exports of cotton and other products. Wright (1990) examined the factor content of U.S. trade in manufactures from 1879 to 1940 and showed that exports were intensive in non-reproducible natural resources. Irwin (2003a) finds that the exploitation of the massive Mesabi iron ore range in the 1890s led to a sharp increase in iron and steel exports.
} 


\subsection{Stable Congressional Voting}

Because political representation is based on geography, regional economic interests should translate into consistent voting patterns in Congress over time. For most of the nation's history, the most important political divide over trade policy has been a geographic one on a North-South axis. This reflected a stark division in the location of trade-affected production. In the early nineteenth century, a manufacturing belt developed that stretched across the Northeast, including cotton textiles in New England and iron in Pennsylvania and Ohio. These industries usually faced competition from imports. Meanwhile, the South produced agricultural crops such as cotton and tobacco that were exported. Consequently, from the time of the 1787 constitutional convention until the Smoot-Hawley tariff in 1930, Congressional voting on trade measures has shown a distinctive North-South split.

To illustrate the persistence of this divide, Figure 2 depicts voting in the House of Representatives on two tariff bills more than a century apart, one in 1828 and another in 1929, the last House vote ever on the tariff schedule. Despite the vast changes in the U.S. economy over that century - including large-scale industrialization, mass immigration, westward movement in population, and enormous technological change - the Congressional vote is remarkably similar. Even today, representatives from the Rust Belt of old manufacturing industries that stretches from upstate New York into the industrial Midwest are largely opposed to trade agreements, while representatives from the South and West tend to be more favorable to such agreements. 
Figure 2: House voting on the tariff in 1828 (left panel) and 1929 (right panel)

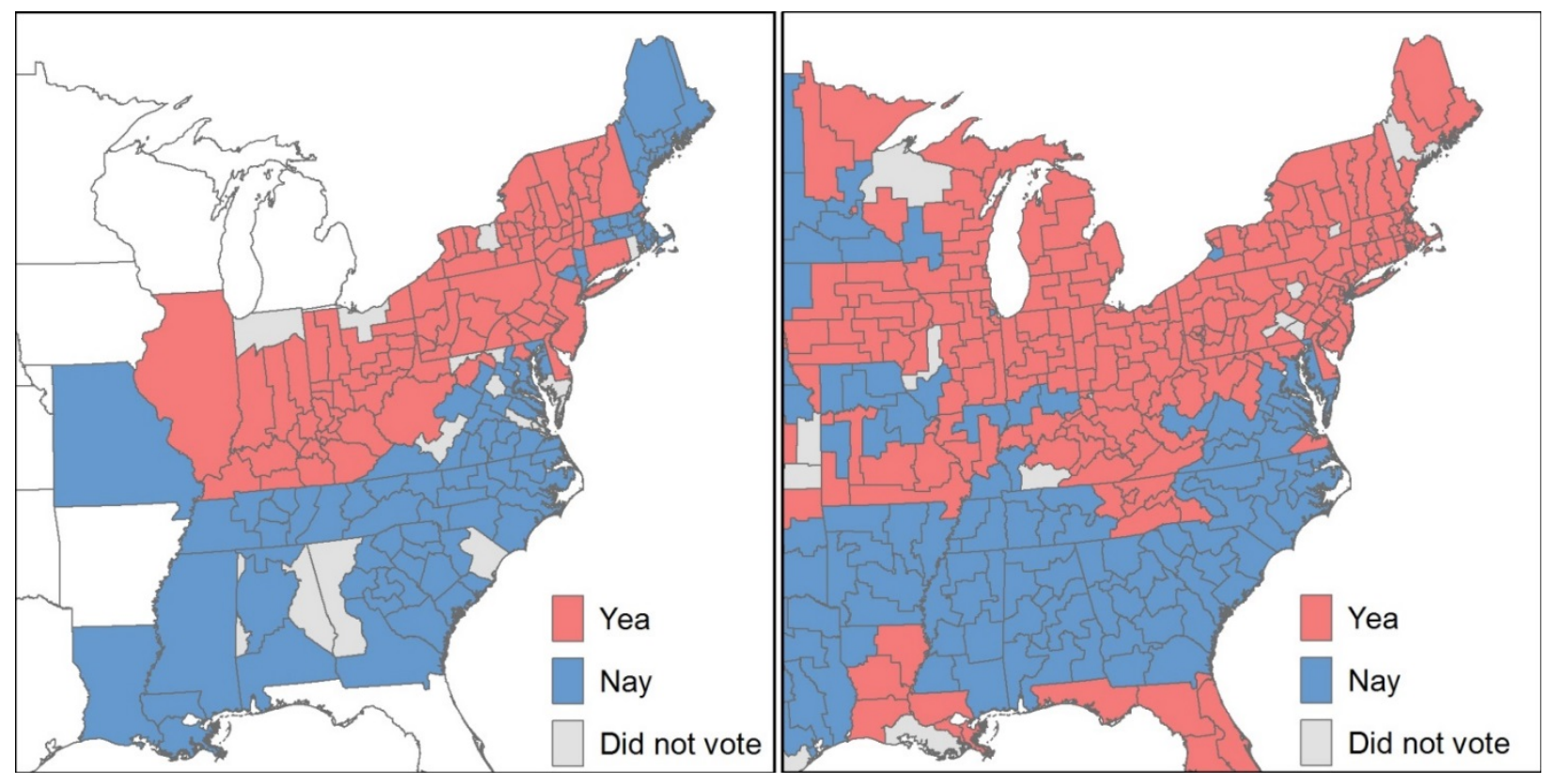

Source: Irwin $(2017,16)$.

\subsection{Stable Tariff Structure}

The structure of the tariff across goods has also been fairly stable over long periods of time. Figure 3 presents a simple scatterplot of the average tariff for the major schedules of the tariff code in 1880 and in 1939 . The tariff rates in 1880, which are largely those that emerged after the Civil War, are highly correlated with those prevailing nearly 60 years later. 
Figure 3: Average Tariff Rate by Schedule, 1880 and 1939

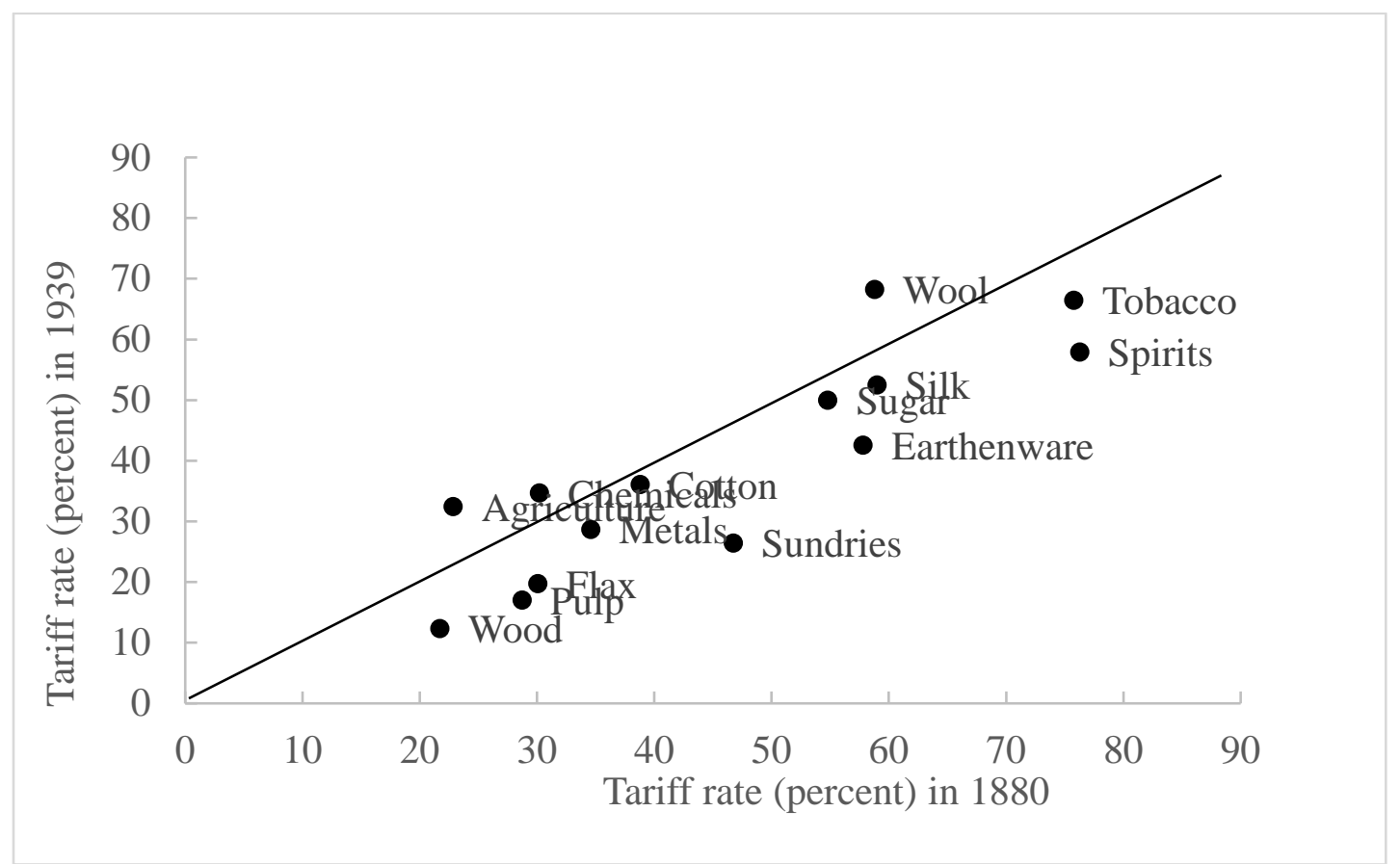

Source: Statistical Abstract of the United States, various issues.

Such an outcome is suggested by the Grossman and Helpman (1994) model of the political economy of trade policy. They derive an expression that explains the structure of tariff rates across industries:

$$
\frac{t_{i}}{\left(1+t_{i}\right)}=\frac{I_{i}-\alpha_{L}}{a+\alpha_{L}} \cdot \frac{x_{i}}{m_{i} \varepsilon_{i}}
$$

where $\mathrm{I}_{\mathrm{i}}$ is an (exogenous) indicator that equals one if industry $\mathrm{i}$ is represented by a lobby group (and zero otherwise), a is the weight put on social welfare in the objective function of politicians, $\alpha_{\mathrm{L}}$ is the (exogenous) share of the population that is represented by lobbies, $\mathrm{x}_{\mathrm{i}} / \mathrm{m}_{\mathrm{i}}$ is the inverse import market share in industry $\mathrm{i}\left(\mathrm{x}_{\mathrm{i}}\right.$ being domestic output and $\mathrm{m}_{\mathrm{i}}$ being imports in sector $\mathrm{i}$ ), and $\varepsilon_{\mathrm{i}}$ is the elasticity of import demand. The protection received by a sector is higher when it is organized, when its output is high relative to competing imports, and when the price responsiveness of the corresponding trade flows is low. Unless the import share, the elasticity, 
the population share, or the weight on social welfare changes, the tariff rates would not be expected to change.

The biggest changes in the tariff usually have been the adjustment of the entire schedule of rates up or down rather than adjustments to the scale of tariff rates across industries. Referring to the equation above, this suggests that the weight on social welfare (a) may change more than the factors affecting particular industries. Such shifts in policy arise from changes in the political power of different political parties or regions of the country. Thus, a move to a lower level of average tariffs (which comes from a change in the weight on social welfare in the model) does not reflect one political faction being more "subservient to the public good” than another, as Madison put it, but simply that an ascendant political faction puts greater weight on exportoriented producer interests than on import-competing producer interests.

\subsection{Partisan Divisions \& Political Rules}

One implication of different regions having different trade-related economic interests is that political parties will take opposing positions on trade policy issues if they draw on different regions for their political support. Each of the three eras of trade policy identified above revenue, restriction, and reciprocity - has occurred in a period in which one political party was politically dominant and could implement its preferred policy. This is summarized in Table 1.

In addition, political rules make it difficult to change policy and help lock-in the policy preferences of the dominant party. The passage of legislation requires the approval of the House of Representatives, the Senate, and the president. This usually can happen only when one party has unified control of government, i.e., when one party controls all three entities. If there is 
divided government, partisan differences make significant policy change unlikely and the status quo remains secure. ${ }^{14}$

\section{Table 1: Three Eras of U.S. Trade Policy}

\begin{tabular}{|l|l|l|l|l|}
\hline Period & Trade Policy Objective & Congressional Voting & $\begin{array}{l}\text { Dominant Political } \\
\text { Party }\end{array}$ & $\begin{array}{l}\text { Region } \\
\text { Represented }\end{array}$ \\
\hline $1837-1860$ & Revenue & Tariff Schedule & Democrats & South \\
\hline $1861-1933$ & Restriction & Tariff Schedule & Republicans & North \\
\hline $1934-1993$ & Reciprocity & $\begin{array}{l}\text { Negotiating Authority \& } \\
\text { Trade Agreements }\end{array}$ & Democrats & Mixed \\
\hline
\end{tabular}

From 1837 to 1860, from the start of the Second party system until the outbreak of the Civil War, the Democratic party dominated American politics. Democrats drew their political strength from the export-oriented South and their rallying cry was "a tariff for revenue only" because of their opposition to protective tariffs. This is why the average tariff fell from the early 1830s to less than 20 percent by 1860, as shown in Figure 1. During this period there were 12 Congresses, 7 with unified governments (6 under the Democrats, 1 under the Whigs) and 5 divided governments. In other words, over this 34 year period, the Whig party from the North that favored higher protective tariffs was only in power for two years. They succeeded in raising tariffs in 1842, but the Democrats promptly reversed this in 1846 after they regained control of government. During the 10 years of divided government, no changes were made to trade policy.

\footnotetext{
${ }^{14}$ The status quo bias applies mainly to the opposition to tariff reductions, as in Fernandez and Rodrik (1991), who point out how domestic producers facing foreign competition are certain to lose but the gains to particular consumers and exporters are uncertain.
} 
From 1861 to 1932, Republicans dominated American politics and drew their political support from the North, where manufacturing interests were concentrated. They wanted high duties to restrict imports, which is why tariffs jumped to 40-50 percent during the Civil War and remained at that level for several decades. During this period there were 35 Congresses, 21 with unified governments (17 Republican, 4 Democratic), and 14 divided governments. Over these 72 years, Democrats only had two opportunities to reduce tariffs, which they did in 1894 and 1913. In each case, these reductions were immediately reversed when Republicans came back into office.

In each of these eras, the existing trade policy was heatedly disputed by the opposition party. The status quo never went unchallenged, with one side or the other complaining that the country would be ruined if tariffs were not raised higher or lowered further. And yet, despite all the debate and controversy, it proved very difficult to dislodge existing policies once they were established. Partisan dominance and political rules enforced a status quo bias that kept trade policy relatively stable within the two eras.

From 1933 to 1993, Democrats again dominated American politics and ensured that reciprocity through trade agreements would reduce tariffs and keep them low. During this period there were 30 Congresses, 16 unified governments (15 Democratic, 1 Republican), and 14 divided governments. During this 60 year period, very few changes were made to the overriding goal of seeking reciprocal trade agreements, even during the two years (1953-55) in which the Republicans had unified control of government.

In the period since 1993, divided government has been more frequent, but the president has usually been in favor of maintaining the status quo or furthering the reduction in trade 
barriers. Donald Trump is the first president since 1930 who seems intent on raising import tariffs and import restrictions, not lowering them in trade agreements.

Figure 4 illustrates the partisan division on trade by showing the percentage of each party in the House voting for lower tariffs (or trade authority or trade agreements) or against higher tariffs. From the 1830s until the 1970s, Democrats were uniformly in favor of lower tariffs. Republicans mainly voted in favor of protective tariffs, although after the Civil War they supported reducing some duties on non-competing imports for consumers, such as tea and coffee. After World War II, however, they began to support trade liberalization. From the early 1950s until the early 1990s, there was a historically anomalous period of bipartisan consensus and the two parties voted in sync with one another. This was during the Cold War when foreign policy concerns were salient and partisan divisions were suppressed (Bailey 2003). Since the NAFTA vote in 1993, just after the end of the Cold War, Democratic support for lower tariffs or trade agreements has diminished considerably. By this time, the political parties had clearly switched positions on trade policy. 
Figure 4: Share of Party Voting (House) for Lower Trade Barriers, 1890-2015

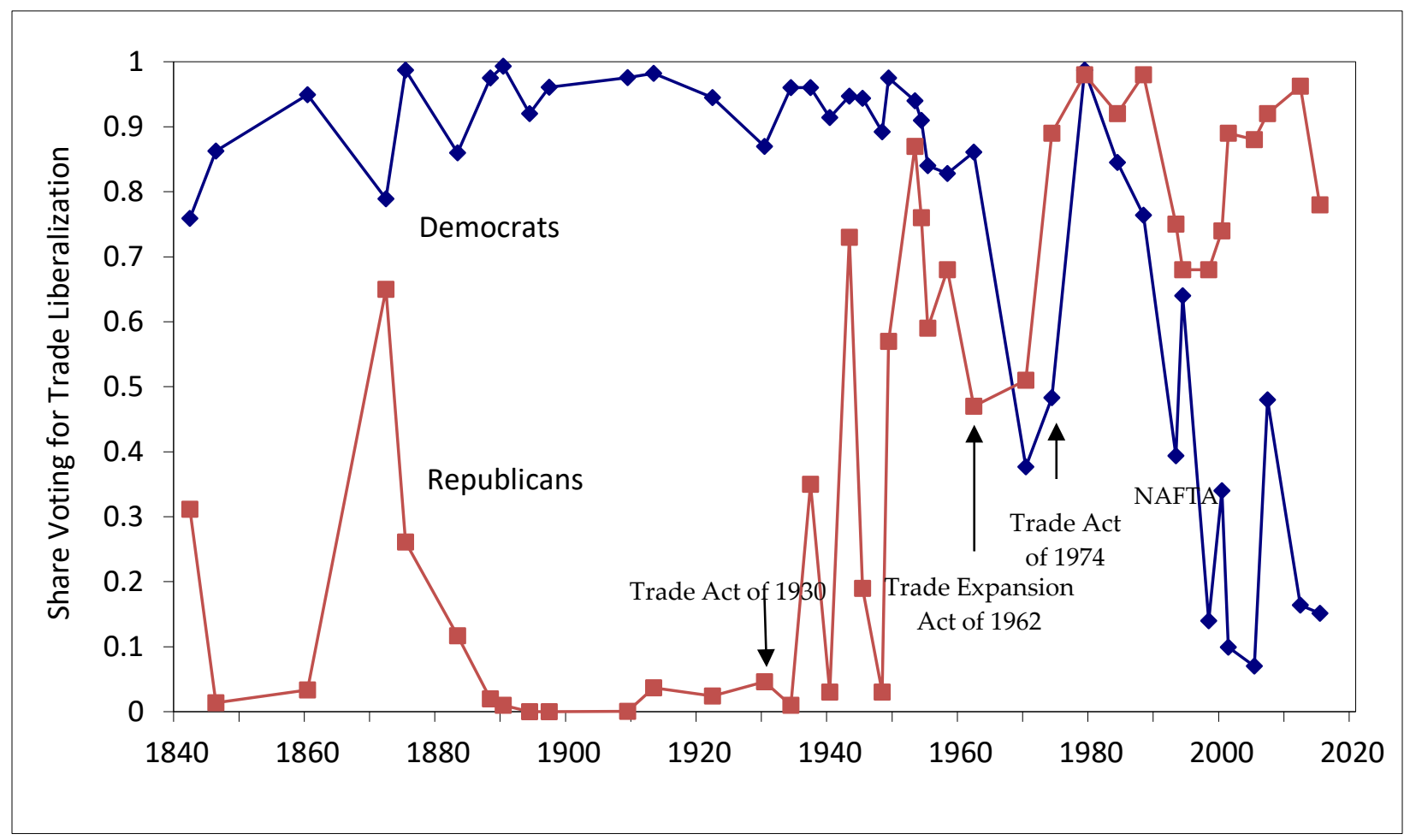

Source: Irwin $(2017,658)$.

This partisan repositioning largely reflects the fact that the parties switched which region of the country they represented: the South flipped from being a region controlled by Democrats to being dominated by Republicans (Kuziemko and Washington 2018), while the Northeast became a stronghold of Democrats. Thus, the regions of the country did not change their trade policy views, but the parties changed which regions of the country they represented.

\subsection{Regime Changes}

The delineation of U.S. tariff history into three periods and three regimes - the revenue, restriction, and reciprocity eras - suggests that there have been only two major shocks in American trade politics that have brought about a shift from one objective to another. The shifts between them resulted from exogenous shocks that realigned political power between regions of 
the country and the political parties representing them. These shocks were the Civil War (186165) and the Great Depression (1929-33).

The Civil War redistributed political power away from the South and toward the North and led to a political realignment in favor of the Republican Party and against the Democratic party. Because Republicans from the North favored protective tariffs, the primary goal of trade policy shifted from revenue to restriction and the average tariff rose accordingly. There was no change in the institutional way in which tariff rates were determined, in that Congress still voted on the tariff schedule in bills that required floor votes, but political power shifted in a way that strengthened import-competing industries located in the North.

The Great Depression led to a political realignment with the Democratic sweep in the 1932 election. This election ended Republican dominance of American politics and ushered in more than five decades of Democratic political control of government. This realignment shifted power to the political party that put greater emphasis on export-oriented interests in the South. As a result, the primary goal of trade policy shifted from restriction to reciprocity and average tariffs fell considerably.

This transition was also marked by an important institutional change in policymaking, namely the delegation of trade-negotiating authority to the president by Congress. In 1934, the Democrats enacted the Reciprocal Trade Agreements Act (RTAA), a landmark piece of legislation that authorized the president to negotiate agreements to reduce tariffs with other countries. $^{15}$

\footnotetext{
${ }^{15}$ Under the RTAA, the Roosevelt administration reached a number of bilateral trade agreements to reduce trade barriers in the 1930s, but their impact on trade was relatively minor (Gowa and Hicks 2018). When the United States became more actively engaged in world affairs during and after World War II, the RTAA proved critical to bringing about important changes in U.S. trade policy. After the war, in an effort to roll back some of the protectionism of the 1930s, the United States helped organize a multilateral conference in 1947 that established the General Agreement on Tariffs and Trade (GATT). The GATT is a legal text regarding commercial policy and remains the principal framework of the world trading system today. In addition, the participating countries agreed on a package of tariff
} 
The RTAA changed the politics of U.S. trade policy. Congress no longer set import duties in long and complicated tariff bills. Rather, the president was authorized to change import duties in trade agreements with other countries. All Congress voted on was the negotiating authority (which included permission to reduce tariffs) or, starting in 1979, the trade agreements themselves. This shifted the locus of trade policy decision-making from the legislative branch, which seemed susceptible to special interest politics and therefore biased in favor of higher tariffs (Grossman and Helpman 2005), to the executive branch, which tended to link trade policy to foreign policy and view trade policy in terms of the national interest. The RTAA also altered the political balance of power toward export interests at the expense of import-competing interests. By directly tying lower foreign tariffs to lower domestic tariffs, the RTAA encouraged exporters to organize in opposition to high tariffs and in support of trade agreements (Haggard 1988, Schnietz 2000, Bailey, Goldstein, and Weingast 1997).

The shift in U.S. trade policy toward trade liberalization was initially secure because the Democrats were politically dominant for many decades after 1934 but became more established when the traditionally protectionist Republicans began to support the RTAA and the GATT. Republicans had consistently rejected the RTAA in the 1930s, but began to change their position in the mid-1940s, as seen in Figure 2. This shift was less due to an ideological conversion in favor of a liberal trade policy as to a new configuration of constituent economic interests and changes in institutional incentives arising from the RTAA and World War II (Bailey, Goldstein, Weingast 1997; Irwin and Kroszner 1998). In particular, World War II so damaged European and Asian economies that foreign competition was no longer a concern for American producers,

reductions, a step toward reducing many trade barriers that had materialized during the Great Depression. Goldstein, Rivers, and Tomz (2007) and Tomz, Goldstein, and Rivers (2007) found that bilateral trade among GATT participants increased by 136 percent, on average, in the first two years of the agreement's existence, compared to trade among nonparticipants. 
many of whom now wanted access to foreign markets to expand their sales. In addition, an important U.S. foreign policy objective at the time was helping allied countries rebuild their economies and resist the threat of communism. These factors led to a bipartisan consensus that trade liberalization was good for the economy and for the nation’s foreign policy (Bailey 2003).

In sum, a combination of political and economic forces gives rise to an underlying stability to U.S. trade policy and makes it difficult to change the direction of policy, thereby ensuring the persistence of the status quo. Two major events, the Civil War and the Great Depression, led to a political realignment that altered the balance of power between contending parties and regions and led to a change in the main objective of trade policy.

\section{The Gains from Trade and Costs of Protection}

In addition to giving us insight into the political economy factors that have shaped U.S. trade policy over the long run, history gives us a perspective on some classic issues of international economics, such as the gains from trade and the costs of protection.

Trade policy was a controversial matter well before the United States became an independent country. The thirteen North American colonies came under the strict regulations of the Navigation Acts, which artificially channeled most of the trade of the colonies through Britain. About three quarters of colonial exports were "enumerated” and had to pass through a British port before being re-exported to other destinations, a policy that reduced the price received by planters in America. There has been a long debate about whether British mercantilist policies enriched British shipping interests at America's expense and thereby contributed to the tensions that gave rise to the American revolution. 
In a pioneering calculation, Lawrence Harper (1939) estimated that these trade restrictions imposed a cost of about 2.3 percent of colonial income in 1773. This calculation did not include the benefits to the colonies of being part of the British Empire, such as savings on defense costs and lower insurance rates on shipping due to the protection provided by the Royal Navy. ${ }^{16}$ This does not mean that British mercantilist restrictions were unimportant in the calls for American independence. About 90 percent of the economic cost of the Navigation Laws is believed to have fallen upon the southern colonies, particularly tobacco planters in Maryland and Virginia. This may have reduced the region's income by as much as 2.5 percent in 1770 and pushed the region into supporting calls for economic independence. ${ }^{17}$

The incomplete data that we have from the period suggests that America's foreign commerce was severely depressed during the Revolutionary War and into the 1780s. Trade picked up in the 1790s but was highly volatile due to military conflicts in Europe. President Thomas Jefferson was responsible for an unusual policy experiment when, with Congress's support, he declared a complete embargo on shipping to and from the United States starting in December 1807. (The ostensible reason for the embargo was to protect American ships and sailors from getting caught in the fighting between Britain and France in the Atlantic.) By mid1808, the United States was almost reduced to a state of autarky, about as close to being completely shut off from international trade as it has ever been in its peacetime history.

The embargo entailed substantial economic costs during the 15 months it was in effect from December 1807 to March 1809. The price of exported goods dropped 20-40 percent immediately, and the price of imported goods rose by about 30 percent as the number of

\footnotetext{
${ }^{16}$ Taking these benefits into account, Thomas (1965) concluded that the net cost of British mercantilist policies to the thirteen colonies was very small, amounting to just 0.6 percent of colonial income.

${ }^{17}$ See Ransom (1968). For example, if tobacco could have been sold directly to European customers, the income of tobacco planters might have been anywhere from 15 to 35 percent higher (Sawers 1992).
} 
American ships returning to U.S. ports slowed to a trickle and imports became increasingly scarce. Irwin (2005) calculates that the static welfare cost of the embargo was about 5 percent of GDP. Arkolakis, Costinot, and Rodrídguez-Clare (2012) show that, for a broad class of models, the gains from trade (as a share of GDP) can be expressed as $1-\lambda_{D}{ }^{1 / \varepsilon}$, where $\lambda_{D}$ is the share of expenditure on domestic goods in the trade equilibrium and $\varepsilon$ is the trade elasticity. In the years prior to the embargo, the import to GDP share was about 20 percent, imports were mainly final goods so $\lambda_{\mathrm{D}}$ is approximately 0.8 , and the trade elasticity is commonly taken to be about 5 . This implies that the cost of moving to autarky was about 4.4 percent, very close to the other calculation. ${ }^{18}$

Of course, the embargo was an extreme event. As Figure 1 showed, the average tariff was in the 20-30 percent range in the 1840s and 1850s. How costly was protection at this time? The tariff distorted production and consumption decisions and created a deadweight loss, as any tax would. Using different methods, Harley (1992b) and Irwin (2010) arrive at similar estimates of the deadweight loss of the tariff in 1859, about 0.5 percent and 0.2 percent of GDP, respectively. The losses are very small because imports as a share of GDP were relatively small.

After the Civil War, in the period of restriction, import tariffs were about 30 percent on total imports and 50 percent on dutiable imports. These higher tariffs produced a much greater deadweight loss. Irwin (2010) calculates the static deadweight welfare loss as a share of gross domestic product using the standard formula $\frac{1}{2} \sum_{n} s_{n} \varepsilon_{n} \tau_{n}^{2}$, where $\mathrm{S}_{\mathrm{n}}$ is the share of imports of good $\mathrm{n}$ in GDP, $\varepsilon_{\mathrm{n}}$ is the elasticity of import demand for good $\mathrm{n}$, and $\tau_{\mathrm{n}}$ is the ad valorem tariff on good n. As shown in Figure 4, tariffs resulted in a sizeable deadweight loss at about 1-1.5 percent

\footnotetext{
${ }^{18}$ Of course, these calculations may understate the welfare losses by ignoring the value of product variety and other considerations.
} 
of GDP immediately after the Civil War, but it declined rapidly to about 0.2 percent of GDP by the early twentieth century. These historical estimates converge to modern calculations of the deadweight loss of tariffs, the first of which were Stern (1964) and Magee (1972), and including those now routinely calculated by the U.S. International Trade Commission (2017). While today the static welfare loss from tariffs is sometimes dismissed as being small, we can see from history that was not always the case.

Figure 5: Static Deadweight Loss from Tariffs (percent of GDP), 1859-2016

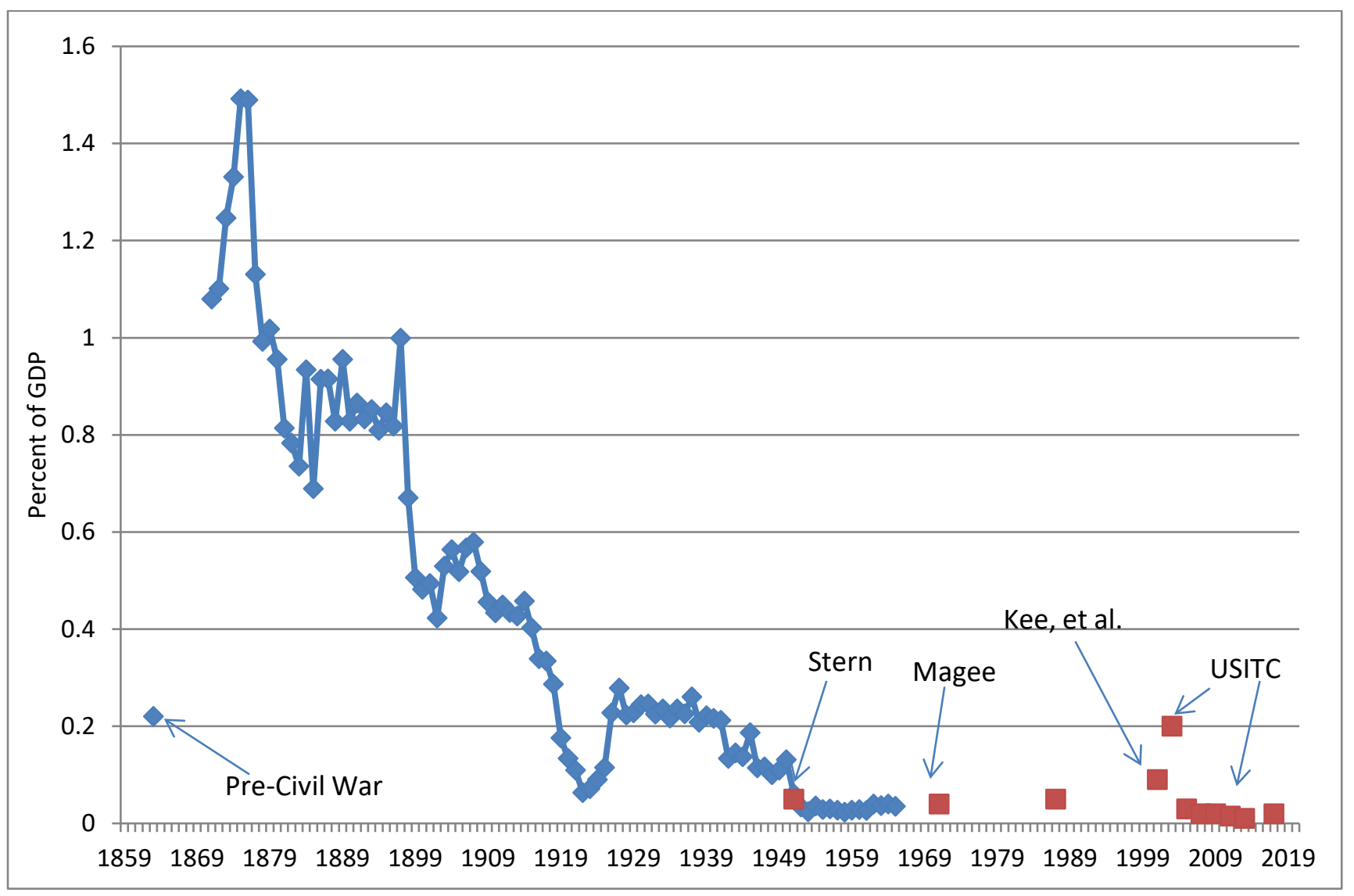

Source: Irwin (2010), updated with USITC (2017)

It is possible, however, that this deadweight loss was more than offset by an improvement in the terms of trade. If a country has the power to affect the price of its exports or imports on 
world markets, an import tariff or export tax can improve its terms of trade, potentially making the country better off as a whole.

This consideration is relevant because the United States produced about 80 percent of the world's cotton in the decades prior to the Civil War and did not take the world price of cotton as given. An export tax that would have been the most direct manner in which the country might have increased the price of its cotton on world markets. Irwin (2003b) estimates that the export demand elasticity for U.S. cotton was about -1.7 and therefore the hypothetical optimal export tax would have been about 50 percent. Such a tax would have raised welfare by about 0.3 percent of GDP, or about 1 percent of the South's GDP, a relatively small amount. Of course, such a policy would have been prohibited under the Constitution.

Could the impact of an export tax have been replicated by an import tariff that indirectly reduced exports? Using a computable general equilibrium model, James (1981) found that the optimal (i.e., welfare-maximizing) tariff for the United States in 1859 was 35-40 percent, higher than its actual level of 20 percent. Moving from the 20 percent tariff to the optimal tariff, he finds, would have increased real income by about 2 percent. However, this result depends on the tariff reducing exports of cotton, the good in which the country had market power. Harley’s (1992b) more detailed model found that import tariffs reduced exports of foodstuffs (the marginal export) and not cotton (the infra-marginal export). He finds that the tariff failed to reduce cotton exports, affect the world price of cotton, or increase national income.

The other market-power based argument for using a tariff to improve economic welfare is to exploit monopsony power and reduce the price of imports. There is much less empirical evidence on this phenomenon. ${ }^{19}$

\footnotetext{
${ }^{19}$ Some evidence is available in the case of sugar. The United States purchased about 20-25 percent of the world's sugar production in the late nineteenth and early twentieth century and changed its tariff several times by
} 
One final note: the United States has never been a typical small open economy. It is a large, economically diverse, continental-sized market which is much less dependent on international trade than most other economies. This means that the magnitude of the gains from trade and the costs of protection are smaller than elsewhere. However, even if the aggregate effects of trade policy were modest, the impacts on different regions of the country have been pronounced and have often had political consequences.

\section{Economic Effects of Trade Policy}

The large size of the U.S. economy has meant that trade has played a limited role in the nation's fortunes. As Figure 6 shows, for much of American history, merchandise exports and imports were only about 5 percent of GDP. The exceptional periods were prior to 1820 and after 1980, when the trade shares were substantially higher. Of course, even when the trade share is small, trade policy can still have a significant domestic impact since it affects the prices of traded goods throughout the economy.

This section looks at the economic effects of trade policy by focusing on three issues of historical controversy: the role of tariffs in redistributing income across regions and groups within the United States, in fostering the industrialization and economic growth of the United States, and in contributing to the Great Depression of the 1930s.

substantially amounts. This variation gives us the opportunity to see how import prices responded to tariff changes. Irwin (2019) examined high frequency data on sugar prices and found a pass-through asymmetry: tariff reductions were fully passed through to consumers, whereas tariff increases were borne by both consumers and foreign producers. 
Figure 6: Merchandise Exports and Imports, percent of GDP, 1790-2018

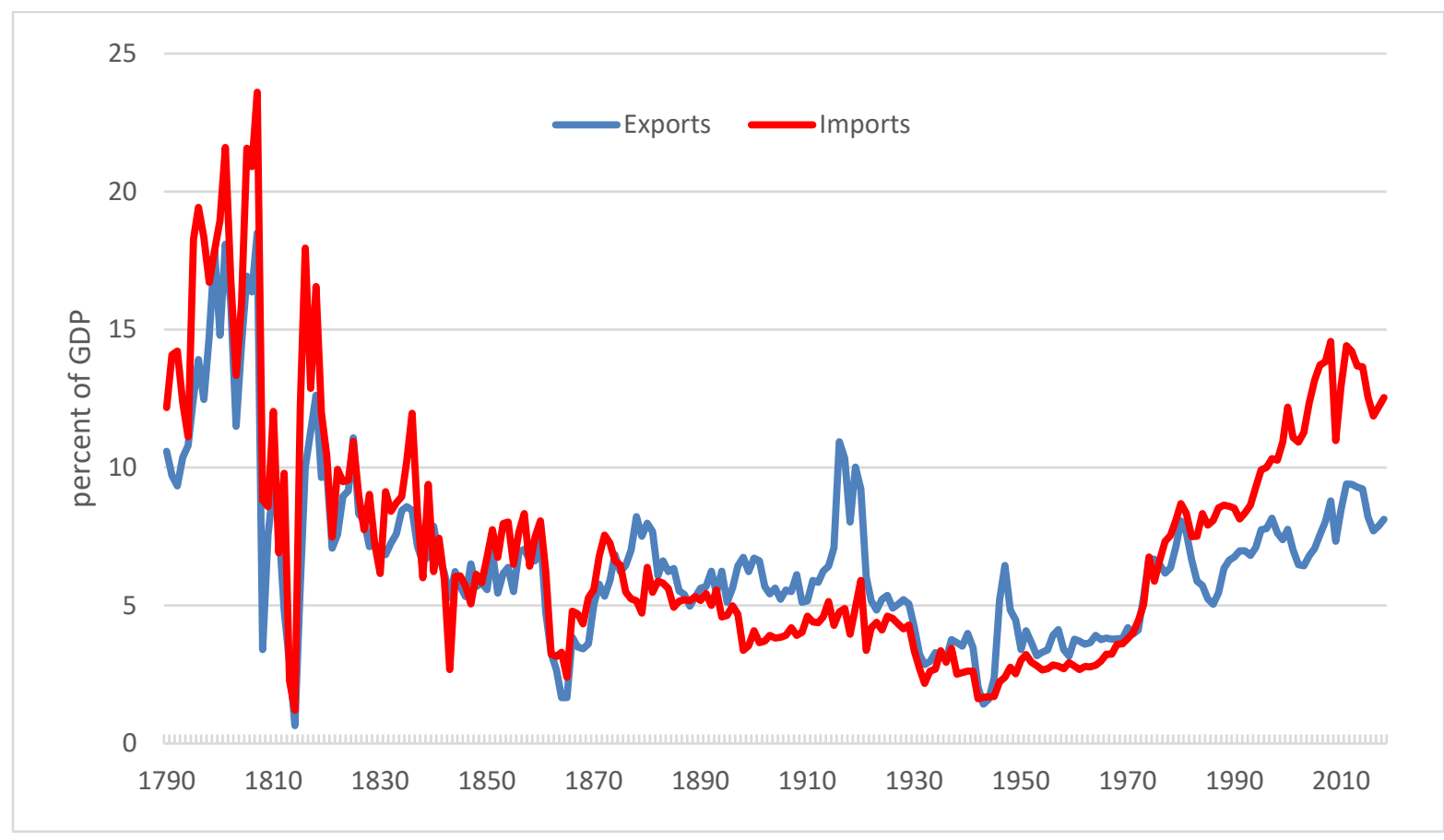

Source: 1790-1928, Historical Statistics of the United States, Millennial Edition (New York: Cambridge University Pres, 2006), updated with Bureau of Economic Analysis.

\subsection{Income Distribution and Sectional Conflict}

In the 1820s, a Congressional coalition including representatives from the North and the Midwest pushed for higher tariffs in 1824 and 1828 (Irwin 2008). By 1830, as Figure 1 shows, the average tariff on imports peaked at about 60 percent, the highest level ever. The South fiercely opposed this development and the controversy sparked the nation's first major political crisis after independence. South Carolina threatened to "nullify" (not enforce) federal tariff legislation and even secede from the union unless tariffs were reduced. This crisis was defused by the Compromise Tariff of 1833, which phased out tariff rates above 20 percent over a nineyear period and essentially remained in place until the Civil War. This established lower tariffs for revenue purposes as government policy for most of the remaining antebellum period. 
Were the South's vociferous objections to a protective tariff justified? Southern critics of the tariff charged that high tariffs on manufactured goods raised the cost of living for consumers and harmed agricultural producers by indirectly reducing their exports. ${ }^{20}$ In addition, they argued, all the revenue from the tariff was spent in the North. Therefore, they viewed high import duties as an unfair tax that redistributed income from consumers and farmers in the South to businesses and capital-owners in the North. Tariff proponents in the North claimed that protective duties helped American workers by expanding industrial employment and boosting wages, while giving farmers a steady demand in the home market for the food and raw materials that they produced.

How much interregional income redistribution was the tariff responsible for? Economic historians have constructed computable general equilibrium models to examine the impact of the tariff on the incomes of different factors of production prior to the Civil War. In Harley's (1992b) calculation for 1859, when the best data is available for the antebellum period, laborers lost a small amount (about 0.5 percent of GDP) while capital-owners gained a small amount (about 0.4 percent of GDP). The largest burden of the tariff was borne by land-owners (farmers and planters), who lost 2-3 percent of GDP. ${ }^{21}$ Like before the American Revolution when British mercantilist policies placed a burden on Southern planters, the antebellum tariff hurt that same group and gave rise to calls for secession.

Another way to consider the incidence of the tariff and how it redistributed income is to focus on how it changed the domestic prices of traded goods relative to non-traded goods. A

\footnotetext{
${ }^{20}$ The South had long recognized the Lerner Symmetry Theorem, that a tax on imports was also a tax on exports. But as noted above, Harley found that import tariffs reduced marginal exports (food and grain) not infra-marginal exports (cotton).

${ }^{21}$ Harley finds that the tariff had a limited impact on income distribution because the average tariff on imports had fallen to less than 20 percent by 1859 and imports were a small share of GDP. Had it been possible to do his calculation for the 1820s, the redistribution might have been greater because the tariff was much higher.
} 
tariff increases the domestic price of importable goods relative to exportable goods, but the benefit for import-competing industries is diminished because the tariff also increases the price of non-traded goods. The higher prices of non-traded goods meant that the average 30 percent tariff during the 1880s amounted to a 17 percent implicit subsidy to domestic import-competing producers and a 10 percent effective tax on exports, according to Irwin (2007). The tariff also redistributed about 8 percent of GDP among various affected groups, but the impact on consumers was only slightly negative because exported goods (particularly food products) loomed large in their consumption bundle.

In sum, economists have long pointed out that trade policy involves distributional fights over income and that the benefits or costs of trade may be concentrated on particular groups or regions of the country. This was very much true in the past and it caused serious political conflict over trade policy, pitting different regions of the country against one another. ${ }^{22}$

\subsection{Economic Growth and Industrialization}

Some of the most controversial questions in economic history hinge on whether trade policy can increase economic growth by shifting resources into the manufacturing sector. In his famous 1791 "Report on Manufactures," Treasury Secretary Alexander Hamilton argued that government policies to subsidize and protect industry might help overcome the many inhibitions and bottlenecks that hampered the start of domestic production. ${ }^{23}$

The United States began a policy of import substitution after the War of 1812, which severely curtailed foreign trade and gave rise to domestic manufacturing. ${ }^{24}$ An important but

\footnotetext{
22 The China Shock is simply a recent example of this phenomenon; see Autor, Dorn, and Hanson (2016).

${ }^{23}$ Irwin (2004) suggests that the report was less "protectionist" than commonly portrayed because Hamilton focused more on promotion through subsidies than protection through tariffs.

${ }^{24}$ By preventing imported manufactured goods from reaching the American market, these disruptions encouraged domestic industries to begin producing manufactured goods that had previously been imported, such as cotton textiles in Massachusetts and iron and glass in Pennsylvania. There is a debate about whether these trade shocks constituted a temporary or permanent boost to manufacturing. Rosenbloom (2004) argues that path dependence
} 
controversial question is how much domestic manufacturing production was dependent on tariff protection prior to the Civil War. Answering that question requires a counterfactual assessment of what would have happened if tariffs had been much lower. The answer depends critically on whether or not imports and domestic output were close substitutes for one another. ${ }^{25}$

The antebellum cotton textile industry has long been studied with these questions in mind. ${ }^{26}$ Taussig $(1931,35)$ suggested that domestic cotton manufactures were strong enough to survive without tariff protection “almost certainly by 1832.” Harley (1992a) disputed this view, suggesting that removal of the tariff would have reduced domestic output of cotton textiles to just 10 percent of domestic consumption even as late as the 1850s. Irwin and Temin (2001) argued that textiles were differentiated products and that American and British producers specialized in quite different varieties of cotton goods. Since domestic producers were insulated from foreign competition by the different characteristics of their products, their evidence suggested that the tariff was relatively unimportant to the survival of the domestic industry. For example, they point out that the cotton textile duties were abruptly slashed in 1846 from about 70 percent to just 25 percent. Imports soared by a factor of three and increased their share of the U.S. market from about 7 percent to about 15 percent, yet domestic production did not decline. ${ }^{27}$

meant that the cotton textile industry might never have gotten off the ground without the interruption of trade. Irwin and Davis (2003) use a new series on industrial production and find that the trade disruptions did not accelerate the trend growth in production but shifted resources from trade-dependent industries (such as shipbuilding) to importsubstituting industries (such as cotton textiles).

${ }^{25}$ If imports and domestic goods were similar products (close substitutes), more imports would presumably reduce domestic production; if imports and domestic goods were dissimilar products (imperfect substitutes), more imports would leave domestic production relatively unaffected.

${ }^{26}$ Thus, whether the Tariff of 1816 was crucial to the preservation of early American industry is unclear. In the case of cotton textiles, Zevin $(1971,128)$ concluded that "while the tariff may have had demand augmenting effects which contributed to the cyclical recovery from the postwar depression, the tariff made no significant contribution to the secular growth of American demand for New England mill products over the period from 1815 to 1833.” In Taussig's $(1931,35)$ view, the early progress of the cotton textile industry, "though perhaps somewhat promoted by the minimum duty of 1816, would hardly have been much retarded in the absence of protective duties."

${ }^{27}$ Of course, in other industries where foreign-produced goods were a close substitute for domestically-produced goods, the tariff may have been important in supporting domestic output. For example, the antebellum iron industry 
After the Civil War, Congress enacted much higher protectionist duties and the United States became an industrial powerhouse. To what extent did the high tariffs help promote industrialization and spur economic growth in this period? If economic growth is based on capital accumulation, technological progress (productivity growth), and the shift of resources (labor and capital) from agriculture to industry and services, then the question then becomes whether protection helped promote capital accumulation, accelerate technological progress, and shift resources toward manufacturing.

In terms of capital accumulation, economic historians have concluded that the increase in the investment rate was largely due to an increase in the savings rate, which was driven by the growth of banking and financial intermediation. ${ }^{28}$ The tariff seems to have played very little role. In fact, De Long (1998) argues that the high tariff on intermediate goods (capital goods) raised the cost of imported equipment, reduced capital accumulation, and thereby slowed economic growth during this period.

In terms of technological progress, the role of the tariff also seems relatively unimportant. According to Kendrick’s (1961) calculations, total factor productivity growth was highest in non-traded sectors (such as transportation, services, utilities, and communications) rather than in agriculture or manufacturing, the sectors most affected by trade. Productivity growth in the

\footnotetext{
was much more vulnerable to foreign competition than the cotton industry. Davis and Irwin (2008) find that domestic iron production was about 30-40 percent greater than it would have been without tariff protection. ${ }^{28}$ The share of capital formation in GDP increased significantly around the time of the Civil War; net investment rose from about 10 percent of GDP before the war to nearly 20 percent of GDP after. Economic historians have concluded that capital accumulation was a savings-driven rather than an investment-driven phenomenon: the relative price of capital goods and real interest rates declined sharply during this period, suggesting that a shift in the supply of savings due to the development of financial markets dominated any shift in investment demand. The growth in savings was facilitated by the National Banking Acts of 1863 and 1864, which helped stabilize the financial system and encourage the entry of more than seven hundred banks during the Civil War era. Jaremski (2014) links these developments to industrial growth in the Midwest.
} 
service sector is usually explained by particular technological innovations - such as railroads, electrification, and the telegraph - none of which seemed to depend on protective tariffs.

Irwin (2001) suggests that protection might have increased growth slightly via by shifting labor and capital resources from agriculture into manufacturing, but only by a small amount. Broadberry (1998) concludes that the United States caught up with and overtook Britain in overall labor productivity largely by shifting resources out of agriculture and improving its relative productivity position in services. Thus, the service sector seems underrated as a factor in driving late nineteenth century economic growth.

Because the aggregate growth effects of trade policy are difficult to establish, more research has been focused on whether tariffs promoted the growth of particular industries. Of course, protecting domestic industries from foreign competition may not put the nation's capital and labor resources into their best use, particularly if protected sectors never becomes efficient enough to survive without protection. However, protection has the potential to increase national welfare if the protected infant industry exhibits learning by doing in which production costs decline with the accumulated production experience at the firm or industry level. In this case, the more production experience, the lower the unit costs of domestic production due to the acquisition of knowledge.

Once again, this question can be addressed only by considering a counterfactual scenario about how an industry would have developed in the absence of the tariff. The strongest candidates for examples of "successful” protection have tended to be in the iron and steel industry. Of course, factors other than the tariff also have to be considered in accounting for the enormous expansion of America's output. The nation's abundance of natural resources, such as 
coal in Pennsylvania and iron ore in Minnesota, has led many to believe that the iron and steel industry would have developed even without the benefit of protection. ${ }^{29}$

The steel rail industry is sometimes proposed as one in which the country benefited from tariff protection. The domestic steel rail industry grew rapidly under protection in the 1870s and 1880s, survived the phased reduction and eventual removal of import duties in the 1890s, and eventually began exporting as American prices fell below British prices, evidence that it became an internationally competitive industry. Head (1994) finds significant learning-by-doing effects that are assumed to spillover perfectly between domestic firms. In performing a counterfactual simulation of what would have happened under free trade, he finds that country-specific learning by doing is so important that the domestic production never begins until almost 1913. The reason is that, without tariffs, the domestic steel rail industry never gains much production experience that would allow it to reduce its costs compared to British producers. ${ }^{30}$ Despite strong learning effects, the steel rail tariff hurt rail users in both the short and long runs, but the tariff's overall effect on welfare was positive but small.

The tinplate industry is also mentioned as a case in which infant industry protection was potentially beneficial. The United States lacked any domestic production of tinplate until the industry received protection under the McKinley tariff of 1890. The industry flourished and grew strong enough to displace imports and even reduce its costs to British levels. In this case, however, static and dynamic scale economies were not substantial and production technology and experience was readily transferable across countries. The failure of the industry to develop

\footnotetext{
${ }^{29}$ In the case of pig iron after the Civil War, Irwin (2000a) finds that if the tariff had been eliminated in 1869, domestic output would fall by about 15 percent and the import market share would rise from about 7 percent to nearly 30 percent. This suggests that a substantial portion of the domestic industry could have survived a significant tariff reduction.

${ }^{30}$ Head's simulation rules out international spillovers of learning-based knowledge, which implies that domestic firms cannot adapt or build upon the production experience of British firms. This essentially ensures that initial producers have an entrenched and virtually insurmountable advantage over subsequent rivals.
} 
was due to the high tariff on iron and steel inputs (which accounted for nearly three quarters of the production costs) rather than the lack of production experience. Irwin’s (2000b) analysis suggested that, in the absence of the McKinley tariff, the domestic tinplate industry would have developed about a decade later as the domestic price of those inputs converged to the world price. Although the tariff succeeded in accelerating the industry’s development, welfare calculations suggest that protection did not pass a cost-benefit test.

\subsection{Smoot-Hawley and the Great Depression}

The Tariff Act of 1930, popularly known as the Smoot-Hawley tariff, was one of the most controversial tariff acts ever enacted by Congress. (It also proved to be the last time Congress revised the entire tariff schedule.) The legislation increased the average tariff on dutiable imports from about 40 percent to 47 percent, but price deflation during the Great Depression help push it up to almost 60 percent in 1932, as shown in Figure 1.

The Smoot-Hawley tariff was enacted just as the world was slipping into a major downturn. The Great Depression from 1929 to 1933 was an economic catastrophe for the United States - real GDP fell by about 25 percent and the unemployment rate rose to more than 20 percent - and the world. As global trade contracted, trade barriers proliferated, and unemployment soared with production falling around the world, the Smoot-Hawley tariff was often blamed for having put the world economy into a tailspin. The degree to which the SmootHawley tariff was responsible for the severity of the Great Depression has been debated ever since. $^{31}$

\footnotetext{
${ }^{31}$ On the general relationship between trade policy and economic growth and macroeconomic fluctuations, see Eichengreen (2019). A related question is why protectionism became so widespread during the Great Depression. Contrary to the presumption that all countries scrambled to raise trade barriers, Eichengreen and Irwin (2010) and Irwin (2012) report substantial cross-country variation the degree to which countries adopted protectionist policies. They find that countries that remained on the gold standard resorted to import quotas and exchange controls to bolster their balance of payments position, whereas countries that left the gold standard and allowed their currencies to depreciate did not adopt such extreme policies to restrict imports. While the 1930 tariff increase by the United
} 
As Irwin (2011) points out, the consensus among most economists is that Smoot-Hawley did not play a significant role in generating the Great Depression. A higher tariff may have changed the composition of domestic production between import-competing and export-oriented industries but did not have large macroeconomic effects, either positive or negative. Monetary policy and financial instability were much more important in driving the economic downturn. The tariff increased the domestic price of imports by just 5 percent at a time when dutiable imports were only 1.4 percent of GDP, making it implausible that a shock of this magnitude could trigger the unprecedented economic contraction experienced after 1930. That said, Bond, Crucini, Potter and Rodrigue (2013) suggest that resource misallocation and lost productivity from the tariff could have magnified the negative impact of the trade channel.

Perhaps the most important ramification of the Smoot-Hawley tariff was its role in triggering retaliation against U.S. exports. Canada, which was heavily dependent on the U.S. market, retaliated almost immediately and imposed tariffs significant enough to put a sizable dent into American exports (McDonald, O’Brien, and Callahan 1997, Irwin 2011). The higher U.S. tariff also abetted the formation of trade blocs that excluded the United States. Britain, along with Canada, moved to establish imperial preferences that discriminated against U.S. trade, as did other trade blocs that emerged during this period. These international developments helped support the domestic political movement for reciprocal trade agreements.

States was an example of special interest politics in Congress, elsewhere in the world it was more a case of secondbest macroeconomic policy when monetary and fiscal policies were constrained by the gold standard and balanced budget rules. 


\section{Conclusion}

This survey has focused on the changing political economy of U.S. trade policy in historical context. The political geography of economic interests, particularly the North-South division that has been evident for much of U.S. history, is key to understanding the trade policies that have emerged. Equally important is the political dominance of certain parties, often representing regional interests, that ensured either revenue, restriction, or reciprocity was the main feature of trade policy. In addition, the survey has considered the impact of trade policy on the development of American industries. Needless to say, there is ample scope for further work on all of these topics, and especially work on how the political geography of trade policy has been changing with the relative decline of manufacturing and the impact of the trade policies of President Donald Trump. 


\section{REFERENCES}

Anderson, James E., and J. Peter Neary. 2005. Measuring the Restrictiveness of International Trade Policy. Cambridge: MIT Press.

Arkolakis, Costas, Arnaud Costinot, and Andrés Rodríguez-Clare. 2012. "New Trade Models, Same Old Gains?” American Economic Review 102: 94-130.

Autor, David H., David Dorn, and Gordon H. Hanson. 2018. "The China Shock: Learning from Labor Market Adjustment to Large Changes in Trade.” Annual Review of Economics 8: 205-40.

Bailey, Michael A. 2003. "The Politics of the Difficult: The Role of Public Opinion in Early Cold War Aid and Trade Policies.” Legislative Studies Quarterly 28:147- 78.

Bailey, Michael A., Judith Goldstein, and Barry R. Weingast. 1997. "The Institutional Roots of American Trade Policy: The Origin and Effects of the Reciprocal Trade Agreements Act.” World Politics 49, 309-338.

Baldwin, Robert E. 1984. "Rent-seeking and Trade Policy: An Industry Approach.” Weltwirtschaftliches Archiv 120: 662-677.

Becker, William H., and William M. McClenahan. 2003. The Market, the State, and the Export-Import Bank of the United States, 1934- 2000. New York: Cambridge University Press.

Blonigen, Bruce. 2011. “Revisiting the Evidence on Trade Policy Preferences.” Journal of International Economics 85:129-135.

Bond, Eric W., Mario Crucini, Tristen Potter, and Joel Rodrigue. 2013. "Misallocation and Productivity Effects of the Hawley-Smoot Tariff.” Review of Economic Dynamics 16:120134.

Broadberry, Stephen N. 1998. "How Did the United States and Germany Overtake Britain? A Sectoral Analysis of Comparative Productivity Levels, 1870-1990.” Journal of Economic History 58, 375-407.

Crucini, Mario J. 1994. "Sources of Variation in Real Tariff Rates: The United States, 1900-1940.” American Economic Review 84, 732-743.

Davis, Joseph H., and Douglas A. Irwin. 2008. “The Antebellum U.S. Iron Industry: Domestic Production and Foreign Competition.” Explorations in Economic History 45, 254-269.

De Long, J. Bradford. 1998. “Trade Policy and America’s Standard of Living: A Historical Persepctive.” In Susan Collins (ed.), Exports, Imports, and the American Worker. Washington, D.C.: The Brookings Institution. 
Eichengreen, Barry. 2019. "Trade Policy and the Macroeconomy.” IMF Economic Review 67: 4-23.

Eichengreen, Barry, and Douglas A. Irwin. 2010. “The Slide to Protectionism in the Great Depression: Who Succumbed and Why?” Journal of Economic History 70: 872-898.

Fernandez, Raquel, and Dani Rodrik. 1991. "Resistance to Reform: Status Quo Bias in the Presence of Individual-Specific Uncertainty.” American Economic Review 81: 1146-155.

Goldstein, Judith L., Douglas Rivers, and Michael Tomz. 2007. "Institutions in International Relations: Understanding the Effects of the GATT and WTO on World Trade.” International Organization 61:37- 67.

Gowa, Joanna, and Raymond Hicks. 2018. “'Big' Treaties, Small Effects: The RTAA Agreements.” World Politics 70: 165-193.

Grossman, Gene M., and Elhanan Helpman. 1994. "Protection for Sale.” American Economic Review 94:833-850.

Grossman, Gene, and Elhanan. Helpman. 2005 “A Protectionist Bias in Majoritarian Politics.” Quarterly Journal of Economics 120: 1239-1282

Harley, C. Knick. 1992a. "International Competitiveness of the Antebellum American Cotton Textile Industry.” Journal of Economic History 52, 559-584.

Harley, C. Knick. 1992b. "The Antebellum American Tariff: Food Exports and Manufacturing.” Explorations in Economic History 29, 375-400.

Haggard, Stephan. 1988. "The Institutional Foundations of Hegemony: Explaining the Reciprocal Trade Agreements Act of 1934.” International Organization 42, 91-119.

Harper, Lawrence A., 1939. The English Navigation Laws. New York: Columbia University Press.

Head, Keith. 1994. "Infant Industry Protection in the Steel Rail Industry." Journal of International Economics 37, 141-165.

Hiscox, Michael J. 2002. International Trade and Political Conflict: Commerce, Coalitions, and Mobility. Princeton: Princeton University Press.

Holmes, Thomas J., and John J. Stevens. 2004. "Spatial Distribution of Economic Activities in North America." In Handbook on Urban and Regional Economics, Vol. 4, edited by J. V. Henderson and J. F. Thisse. Amsterdam: North Holland.

Irwin, Douglas A. 1998a. "Changes in U.S. Tariffs: The Role of Import Prices and Commercial Policies,” American Economic Review 88, 1015-1026. 
Irwin, Douglas A. 1998b. "Higher Tariffs, Lower Revenues? Analyzing the Fiscal Aspects of the 'Great Tariff Debate of 1888,'” Journal of Economic History 58: 59-72.

Irwin, Douglas A. 2000a. “Could the U.S. Iron Industry Have Survived Free Trade After the Civil War?” Explorations in Economic History 37, 278-299.

Irwin, Douglas A. 2000b. "Did Late Nineteenth Century U.S. Tariffs Promote Infant Industries? Evidence from the Tinplate Industry,” Journal of Economic History 60, 335-360.

Irwin, Douglas A. 2001. "Tariffs and Growth in Late Nineteenth Century America.” The World Economy 24, 15-30.

Irwin, Douglas A. 2003a. "Explaining America's Surge in Manufactured Exports, 18801913.” Review of Economics and Statistics 85, 364-76.

Irwin, Douglas A. 2003b. “The Optimal Tax on Antebellum Cotton Exports,” Journal of International Economics 60, 275-291.

Irwin, Douglas A. 2004. “The Aftermath of Hamilton’s Report on Manufactures,” Journal of Economic History 64, 800-821.

Irwin, Douglas A. 2005. "The Welfare Costs of Autarky: Evidence from the Jeffersonian Embargo, 1807-1809.” Review of International Economics 13, 631-645.

Irwin, Douglas A. 2007. “Tariff Incidence in America’s Gilded Age,” Journal of Economic History 67, 582-607.

Irwin, Douglas A. 2008. "Antebellum Tariff Politics: Regional Coalitions and Shifting Economic Interests,” Journal of Law and Economics 51, 715-742.

Irwin, Douglas A. 2010. "Trade Restrictiveness and Deadweight Losses from U.S. Tariffs.” American Economic Journal: Economic Policy 2: 111-133.

Irwin, Douglas A. 2011. Peddling Protectionism: Smoot-Hawley and the Great Depression. Princeton: Princeton University Press. MIT Press.

Irwin, Douglas A. 2012. Trade Policy Disaster: Lessons from the 1930s. Cambridge:

Irwin, Douglas A. 2017. Clashing over Commerce: A History of U.S. Trade Policy. Chicago: University of Chicago Press.

Irwin, Douglas A. 2019. “Tariff Incidence: Evidence from U.S. Sugar Duties, 18901914.” National Tax Journal, forthcoming. 
Irwin, Douglas A., and Joseph H. Davis. 2003. “Trade Disruptions and America’s Early Industrialization.” NBER Working Paper No. 9944.

Irwin, Douglas A., and Randall S. Kroszner. 1999. “Interests, Institutions, and Ideology in Securing Policy Change: The Republican Conversion to Trade Liberalization after SmootHawley." Journal of Law and Economics 42: 643-673.

Irwin, Douglas A., and Peter Temin. 2001. "The Antebellum Tariff on Cotton Textiles Revisited.” Journal of Economic History 61, 777-798.

James, John A. 1981. "The Optimal Tariff in the Antebellum United States.” American Economic Review 71, 726-34.

Jaremski, Matthew. 2014. "National Banking’s Role in U.S. Industrialization.” Journal of Economic History 74:109- 40.

Kee, Hiau Looi, Alessandro Nicita, and Marcelo Olarreaga. 2008. "Import Demand Elasticities and Trade Distortions.” Review of Economics and Statistics 90: 666-82.

Kendrick, John W. 1961. Productivity Trends in the United States. Princeton: Princeton University Press.

Kuziemko, Ilyana, and Ebonya Washington. 2018. "Why did the Democrats Lose the South? Bringing New Data to an Old Debate.” American Economic Review 108:2830-67.

Magee, Stephen P. 1972. “The Welfare Effects of Restrictions on U.S. Trade.” Brookings Papers on Economic Activity 3: 645-707.

Mayer, Wolfgang. 1984. “Endogenous Tariff Formation.” American Economic Review 74: 97085.

McDonald, Judith A., Anthony Patrick O’Brien, and Colleen M. Callahan. 1997. “Tariff Wars: Canada’s Reaction to the Smoot-Hawley Tariff.” Journal of Economic History 57, 802-26.

Ransom, Roger L. 1968. "British Policy and Colonial Growth: Some Implications of the Burden from the Navigation Acts.” Journal of Economic History 28, 427-435.

Rosenbloom, Joshua. 2004. "Path Dependence and the Origins of the American Cotton Textile Industry.” In David Jeremy and Douglas A. Farnie, eds. The Fibre that Changed the World: Cotton Industry in International Perspective (Oxford: Oxford University Press. 262-284.

Sawers, Larry. 1992. “The Navigation Acts Revisited.” Economic History Review 45, 
Schnietz, Karen. 2000. “The Institutional Foundations of U.S. Trade Policy: Revisiting Explanations for the 1934 Reciprocal Trade Agreements Act.” Journal of Policy History 12, 417-44.

Stern, Robert M. 1964. "The U.S. Tariff and the Efficiency of the U.S. Economy.” American Economic Review 54: 459-70.

Taussig, Frank. 1931. A Tariff History of the United States. $8^{\text {th }}$ edition. New York: Putnam.

Thomas, Robert P. 1965. “A Quantitative Approach to the Study of the Effects of British Imperial Policy upon Colonial Welfare: Some Preliminary Findings.” Journal of Economic History 25, 615-638.

Tomz, Michael, Goldstein, Judith L., and Rivers, Douglas. 2007. "Do We Really Know that the WTO Increases Trade? Comment.” American Economic Review 97: 2005-18.

United States International Trade Commission. 2017. The Economic Effects of Significant U.S. Import Restraints, Ninth Update 2017. Investigation No. 332-325. Publication 3906. http://www.usitc.gov/publications/332/pub3906.pdf.

Wright, Gavin. 1990. “The Origins of American Industrial Success, 1879-1940.” American Economic Review 80: 651-668.

Zevin, Robert B. 1971. “The Growth of Cotton Textile Production after 1815.” In Robert Fogel and Stanley Engerman (eds.), The Reinterpretation of America's Past. New York: Harper \& Row. 